\title{
SPHERICAL FUZZY SWARA-MARCOS APPROACH FOR GREEN SUPPLIER SELECTION
}

\author{
Mehmet Ali Taş \\ Department of Industrial Engineering, Turkish-German University. \\ Istanbul, (Turkey). \\ E-mail:mehmetali.tas@tau.edu.tr \\ ORCID: https://orcid.org/0000-0003-3333-7972 \\ Esra Çakır \\ Department of Industrial Engineering, Galatasaray University \\ Istanbul, (Turkey). \\ E-mail: ecakir@gsu.edu.tr \\ ORCID: https://orcid.org/0000-0003-4134-7679
}

Ziya Ulukan

Department of Industrial Engineering, Galatasaray University

Istanbul, (Turkey).

E-mail:zulukan@gsu.edu.tr

ORCID: https://orcid.org/ 0000-0003-4805-2726

Recepción: 01/12/2020 Aceptación: 22/02/2021 Publicación: 07/05/2021

\section{Citación sugerida:}

Taş, M. A., Çakır, E., y Ulukan, Z. (2021). Spherical fuzzy SWARA-MARCOS approach for green supplier selection. 3 C Tecnología. Glosas de innovación aplicadas a la pyme, Edición Especial, (mayo 2021), 115133. https://doi.org/10.17993/3ctecno.2021.specialissue7.115-133 


\section{ABSTRACT}

In a supply chain management, supplier selection is an important step to determine the structure of the model. Multi-criteria decision making methods are appropriate tools for dealing with the selection of suitable suppliers. In addition, fuzzy multi-criteria decision making approaches are helpful to include different and uncertain views of decision makers. In this study, a new combined fuzzy methodology is proposed to handle green supplier selection problem. The proposed model consists of a spherical fuzzy-SWARA method, which is used to calculate the criteria weights, and MARCOS method, which is applied to rank the alternatives. In the case study, green supplier selection problem of a textile company located in Turkey is discussed. Six alternative suppliers are evaluated against twelve green criteria, and alternatives are ranked. Finally, a sensitivity analysis is performed to compare the results of different scenarios.

\section{KEYWORDS}

Green supplier selection, MARCOS, MCDM, Spherical fuzzy sets, Supply chain, Spherical fuzzy - SWARA. 


\section{INTRODUCTION}

Supply chains are of great importance for businesses to maintain their main activities (Stevens, 1989). For the establishment and proper functioning of supply chains, the appropriate supplier must be selected. The criteria (attributes) to be considered when choosing a supplier often conflict with each other and cause difficulty in decision making (Akcan \& Taş, 2019). Multi-criteria decision-making methods (MCDM) can be used to overcome these difficulties. These methods help to evaluate alternatives using criteria with different characteristics (De Boer et al., 2001). In addition, it is appropriate to use fuzzy sets for imprecise statements of decision makers. These methods are frequently used in supplier selection practices (Yazdani et al., 2017). In recent years, thanks to the increase in environmental awareness, sustainable supply chain has gained importance. Therefore, the concept of green supply chain that cares about the environment has emerged (Bali et al., 2013). Sustainable criteria should be taken into account and determined as environmental performance evaluations. Using the MCDM methods, the suitable supplier in the green supply chain can be determined according to the sustainable criteria. Various MCDM have been used for green supplier selection in the literature, including some methods such as AHP (Mavi, 2015), PROMETHEE (Govindan et al., 2017), TOPSIS (Cao et al., 2015), ANP (Chung et al., 2016), DEA (Dobos \& Vörösmarty, 2019), VIKOR (Akman, 2015), ELECTRE (Kumar et al, 2017), COPRAS (Liou, 2016), DEMATEL (Hsu, 2013), EDAS (He, 2019), TODIM (Sang \& Liu, 2016), WASPAS (Ghorabaee, 2016), MULTIMOORA (Sen et al., 2017), and more. In this study, SWARA and MARGOS are combined with spherical fuzzy sets (SFS) for fuzzy MCDM problems.

SWARA method was introduced to the literature by Keršuliene et al. (2010). The method was applied to evaluate the criteria for the selection of agile supplier of an automobile manufacturer in Iran (Alimardan et al., 2013), the evaluation of investments in high technology sectors (Hashemkhani \& Bahrami, 2014), the design of bottle package (Stanujkic et al., 2015), the selection of renewable energy technology (Ijadi Maghsoodi et al., 2018), the appraisal of sustainable properties for renewable energy systems (Ghenai et al., 2020).

After Zadeh (1965) introduce the ordinary fuzzy sets, numerous extensions have been proposed such as type-2 fuzzy sets (Zadeh, 1975), intuitionistic fuzzy sets (Atanassov, 
1986), hesitant fuzzy sets (Torra, 2010), Pythagorean fuzzy sets (Yager, 2013), neutrosophic fuzzy sets (Smarandache, 1998), and so on. In the literature, many research combined SWARA and fuzzy sets. Some of these are those: ordinary fuzzy-SWARA (Perçin, 2019), hesitant fuzzy-SWARA (Kaya \& Erginel, 2020), symmetric interval type-2 fuzzy-SWARA (Keshavarz-Ghorabaee, 2018), neutrosophic fuzzy-SWARA (Rani \& Mishra, 2020). In 2018, as an extension of fuzzy sets, spherical fuzzy numbers are introduced (Gündoğdu \& Kahraman, 2019a). These fuzzy sets differ from others in that they are three-dimensional. "In spherical fuzzy numbers, while the squared sum of membership, non-membership and hesitancy parameters can be between 0 and 1 , each of them can be defined between 0 and 1 independently to satisfy that their squared sum is at most equal to 1" (Gündoğdu \& Kahraman, 2019b). Additionally, this study proposes a new spherical fuzzy-SWARA combination to the literature.

The Measurement of Alternatives and Ranking according to Compromise Solution (MARCOS) method is first introduced to the literature by Stević et al. (2020). Ilieva et al. (2020) used fuzzy MARCOS for ordering cloud storage service. Chattopadhyay et al. (2020) conducted a supplier selection study for the iron and steel industry using D-MARCOS. Stević and Brković (2020) used integrated FUCOM-MARCOS methodology to evaluate the human resources of the transportation company and to select the employee of the month. Stanković et al. (2020) studied on the risks of the main road with the fuzzy MARCOS. Badi and Pamucar (2020) used MARCOS with gray numbers in the supplier selection of Libyan Iron and Steel Company. Vesković et al. (2020) assessed possible solutions to problems of railway transportation in Republic of Srpska. F-MARCOS was chosen as one of the MCDM methods to compare the results. Mijajlović et al. (2020) employed FUCOM and fuzzy MARCOS to examine the competition of spa centers. Ulutaş et al. (2020) researched on the manual stacker selection for small warehouses, using CCSD, ITARA, and MARCOS. They used the MARCOS to evaluate the alternatives. Puška et al. (2020) performed MARCOS in selection of project management software.

In this study examines the green supplier selection problem of a textile firm. To examine environmental performance, twelve green criteria are determined. Seven decision makers (DM) working within the company evaluate the criteria and alternatives with the spherical fuzzy numbers. The weights of the criteria are calculated by the spherical fuzzy-SWARA 
method. Applying the steps of the MARCOS, the alternatives are ranked. In the lights of the literature review, the original contribution of this study is that the proposed methodology is the pioneering work that combines spherical fuzzy-SWARA and MARCOS method. In addition, the proposed methodology is adapted to a real-life problem by investigating a green supplier selection case.

The rest of the paper is organized as follows. The preliminaries and definitions of the spherical fuzzy sets are given in Section 2. The proposed methodology involving the original combination of the spherical fuzzy-SWARA and MARCOS methods are also introduced in Section 2. Section 3 applies the proposed methodology on a green supplier selection case and a sensitivity analysis is applied for different weighting criteria scenarios. Finally, conclusion and future perspectives are discussed in Section 4.

\section{METHODOLOGY}

\subsection{PRELIMINARIES}

This section gives the preliminaries and definitions of the proposed method with spherical fuzzy information (Gündoğdu \& Kahraman, 2019a; Gündoğdu \& Kahraman, 2019b):

Definition 1: A spherical fuzzy set $\tilde{A}$ of the universe of discourse $\mathrm{X}$ is given by:

$$
\tilde{\mathrm{A}}=\left\{\left(x, \mu_{A}(x), \eta_{A}(x), v_{A}(x)\right) \mid x \in X\right\}
$$

The $\mu_{\tilde{\AA}}(\mathrm{x}), \eta_{\tilde{\AA}}(\mathrm{x})$ and $v_{\tilde{\mathrm{A}}}(\mathrm{x})$ represent membership degree, non-membership degree and hesitancy of $\mathrm{x}$ to $\tilde{\mathrm{A}}$, respectively and they satisfy the condition $\mu_{\tilde{\AA}}(x), \eta_{\tilde{\AA}}(x), v_{\tilde{\AA}}(x) \in[0,1]$ ve $0 \leq \mu_{\tilde{\AA}}(x)^{2}+\eta_{\tilde{A}}(x)^{2}+v_{\tilde{\AA}}(x)^{2} \leq 1$. The hesitancy parameter of $\tilde{\mathrm{A}}$ is expressed as $\pi_{\tilde{\AA}}(\mathrm{x})=\sqrt{1-\mu_{\tilde{\mathrm{A}}}(x)^{2}-\eta_{\tilde{\mathrm{A}}}(x)^{2}-v_{\tilde{\mathrm{A}}}(x)^{2}}$. The expression $\left(\mu_{\tilde{\mathrm{A}}}(\mathrm{x}), \eta_{\tilde{\mathrm{A}}}(\mathrm{x}), v_{\tilde{\mathrm{A}}}\right.$ $(\mathrm{x}))$ is simply called the spherical fuzzy number $(\mathrm{SFN})$, which can be represented as $\alpha=(\mu$, $\eta$, v). In Figure 1, the spherical fuzzy set is illustrated. 


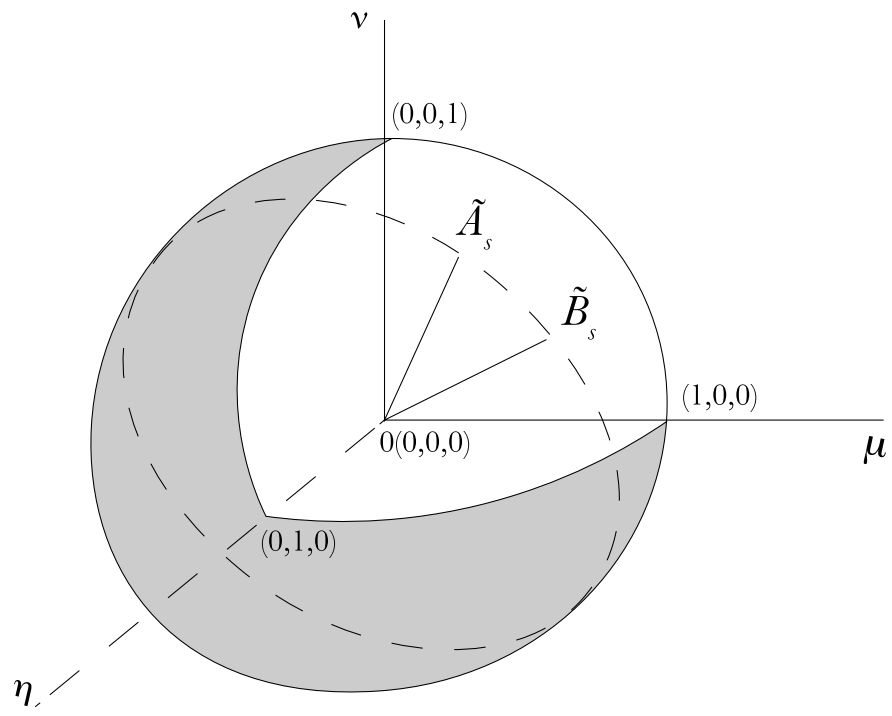

Figure 1. Geometric representation of SFS.

Source: (Gündoğdu \& Kahraman, 2019b).

Definition 2: Let $a_{1}=\left(\mu_{1}, \eta_{1}, v_{1}\right)$ and $a_{2}=\left(\mu_{2}, \eta_{2}, v_{2}\right)$ be two SFN and let $\lambda$ be a positive real number, then:

$$
\begin{aligned}
& \alpha_{1} \oplus \alpha_{2}=\left\{\sqrt{\mu_{1}{ }^{2}+\mu_{2}{ }^{2}-\mu_{1}{ }^{2} \mu_{2}{ }^{2}}, \eta_{1} \eta_{2} \sqrt{\left(1-\mu_{2}{ }^{2}\right) v_{1}{ }^{2}+\left(1-\mu_{1}{ }^{2}\right) v_{2}{ }^{2}-v_{1}{ }^{2} v_{2}{ }^{2}}\right\} \\
& \alpha_{1} \otimes \alpha_{2}=\left\{\mu_{1} \mu_{1}, \sqrt{\eta_{1}{ }^{2}+\eta_{2}{ }^{2}-\eta_{1}{ }^{2} \eta_{2}{ }^{2}}, \sqrt{\left(1-\eta_{2}{ }^{2}\right) v_{1}{ }^{2}+\left(1-\eta_{1}{ }^{2}\right) v_{2}{ }^{2}-v_{1}{ }^{2} v_{2}{ }^{2}}\right\} \\
& \lambda \alpha_{1}=\left\{\sqrt{1-\left(1-\mu_{1}^{2}\right)^{\lambda}}, \eta_{1}^{\lambda}, \sqrt{\left(1-\mu_{1}^{2}\right)^{\lambda}+\left(1-\mu_{1}^{2}-v_{1}^{2}\right)^{\lambda}}\right\} \\
& \alpha_{1}^{\lambda}=\left\{\mu_{1}^{\lambda}, \sqrt{1-\left(1-\eta_{1}{ }^{2}\right)^{\lambda}}, \sqrt{\left(1-\eta_{1}{ }^{2}\right)^{\lambda}+\left(1-\eta_{1}{ }^{2}-v_{1}{ }^{2}\right)^{\lambda}}\right\}
\end{aligned}
$$

The complement of the spherical fuzzy number $a=(\mu, \eta, v)$ is defined as follows:

$$
a^{C}=(\mathrm{v}, \mathrm{\eta}, \mu)
$$

\subsection{PROPOSED METHODOLOGY}

In this section, the steps of combined the spherical fuzzy-SWARA and MARCOS methods are introduced. Firstly, the spherical fuzzy-SWARA method is given to calculate the weights of the criteria and then, MARCOS (Stević et al., 2020) method is applied to rank of the alternatives. This study implements the spherical fuzzy sets to SWARA (Stanujkic et al., 2015) steps as follows:

Step 1. Set the problem and select the experts/decision makers according to the problem. 
Step 2. Ranking the criteria by the spherical fuzzy-SWARA. Criteria are ranked based on DM evaluations. The ranking is from highest importance to lowest.

Step 2.1. Determine $\tilde{s_{j}}$ value: $\tilde{s_{j}}$ is named "comparative importance of average value" by linguistic measures in Table 1 .

Table 1. Linguistic measures of importance used for comparison.

\begin{tabular}{|c|c|}
\hline Linguistic measures & $(\boldsymbol{\mu}, \boldsymbol{\eta}, \mathbf{v})$ \\
\hline Equally Importance (EI) & $(0.5,0.4,0.4)$ \\
\hline Slightly Low Importance (SLI) & $(0.4,0.6,0.3)$ \\
\hline Low Importance (LI) & $(0.3,0.7,0.2)$ \\
\hline Very Low Importance (VLI) & $(0.2,0.8,0.1)$ \\
\hline Absolutely Low Importance (ALI) & $(0.1,0.9,0.0)$ \\
\hline
\end{tabular}

Source: (Gündoğdu \& Kahraman, 2019b).

Step 2.2. Determine $\tilde{k_{j}}$ coefficient: $\tilde{k_{j}}$ coefficient is calculated using Eq. (7):

$$
\left\{\begin{aligned}
(0.5,0.4,0.4) & j=1 \\
\tilde{s}_{j}+(0.5,0.4,0.4) & j>1
\end{aligned}\right.
$$

Step 2.3. Calculate the scores of $\tilde{k}_{j}$ coefficient: the scores of the $\tilde{k}_{j}$ is calculated with Eq. (8):

$$
\operatorname{SI}\left(\tilde{k}_{j}\right)=\sqrt{\left|100 *\left[\left(\mu_{\tilde{k}_{j}}-v_{\tilde{k}_{j}}\right)^{2}-\left(\eta_{\bar{k}_{j}}-v_{\bar{k}_{j}}\right)^{2}\right]\right|} \text { for } \mu_{\tilde{k}_{j}} \geq v_{\bar{k}_{j}}
$$

Step 2.4. Determine $q_{j}$ value: The importance vector value $q_{j}$ is calculated with Eq. (9):

$$
\left\{\begin{array}{cc}
1 & j=1 \\
\frac{x_{j-1}}{k_{j}} & j>1
\end{array}\right.
$$

Step 2.5. Determine $w_{j}$ value: $w_{j}$ values are the weights of the criteria, which is calculated using Eq. (10):

$$
w_{j}=\frac{q_{j}}{\sum_{k=1}^{n} q_{k}}
$$

Step 3. Ranking the criteria by MARCOS (Stević et al., 2020). Creating an initial decision matrix.

Step 3.1. Extend the initial decision matrix. Ideal (AI) and Anti-ideal (AAI) solutions are included to the matrix. Ideal (AI) solution is the best alternative. The below is the expression of ideal (AI) solution (Eq. 11): 


$$
A I={ }_{i}^{\max } x_{i j} \text { if } j \in B \text { and }{ }_{i}^{\min } x_{i j} \text { if } j \in C
$$

Anti-ideal (AAI) solution is the worst alternative. The expression of anti-ideal (AAI) solution (Eq. 12) is as follows:

$$
A A I={ }_{i}^{\min } x_{i j} \text { if } j \in B \text { and }{ }_{i}^{\max } x_{i j} \text { if } j \in C
$$

Here, C symbolizes cost criteria to be minimized, whereas B symbolizes benefit criteria to be maximized. The extended decision matrix $(\mathrm{X})$ is shown below:

$$
X=\begin{gathered}
A A I \\
A_{1} \\
\ldots \\
A_{m} \\
A I
\end{gathered}\left[\begin{array}{ccc}
x_{a a 1} & \ldots & x_{a a n} \\
x_{11} & \ldots & x_{1 n} \\
\ldots & \ldots & \ldots \\
x_{m 1} & \ldots & x_{m n} \\
x_{a i 1} & \ldots & x_{a i n}
\end{array}\right]
$$

Step 3.2. Normalize of matrix " $\mathrm{X}$ " with Eq. (13) and (14) for benefit criteria and cost criteria, respectively. $x_{i j}$ and $x_{a i}$ belong to matrix " $\mathrm{X}$ ".

$$
\begin{aligned}
& n_{i j}=\frac{x_{i j}}{x_{a i}} \text { if } J \in B \\
& n_{i j}=\frac{x_{a i}}{x_{i j}} \text { if } J \in C
\end{aligned}
$$

Step 3.3. Creating the weighted matrix "V" using Eq. (15). $w_{j}$ values represent criteria weights which are calculated or determined.

$$
v_{i j}=n_{i j} \times w_{j}
$$

Step 3.4. Calculate the $S_{i}$ and $K_{i} . S_{i}$ stands for the sum of $v_{i j}$ and $K_{i}$ stands for the utility degree of alternatives. The values are calculated using Eq. (16), (17) and (18) below.

$$
\begin{aligned}
& S_{i}=\sum_{i=1}^{n} v_{i j} \\
& K_{i}^{+}=\frac{S_{i}}{S_{a i}} \\
& K_{i}^{-}=\frac{S_{i}}{S_{a a i}}
\end{aligned}
$$


Step 3.5. Formulate the utility function. $f\left(K_{i}^{+}\right)$and $f\left(K_{i}^{-}\right)$are used for the utility function with respect to the ideal and anti-ideal solution, respectively. These values are calculated using Eq. (19), (20) and (21) below.

$$
\begin{gathered}
f\left(K_{i}^{+}\right)=\frac{K_{i}^{-}}{K_{i}^{+}+K_{i}^{-}} \\
f\left(K_{i}^{-}\right)=\frac{K_{i}^{+}}{K_{i}^{+}+K_{i}^{-}} \\
f\left(K_{i}\right)=\frac{K_{i}^{+}+K_{i}^{-}}{1+\frac{1-f\left(K_{i}^{+}\right)}{f\left(K_{i}^{+}\right)}+\frac{1-f\left(K_{i}^{-}\right)}{f\left(K_{i}^{-}\right)}}
\end{gathered}
$$

Step 3.6. Create the ranking of alternatives.

Step 4. Determining the best alternative which is the one with the highest score.

\section{CASE STUDY}

A textile manufacturer located in Marmara region in Turkey is selected as a case study of proposed model. The firm operates in the international market. Twelve sustainable criteria have been determined for the evaluation of six alternative suppliers, which supply raw materials. These green criteria are given in Table 2.

Table 2. The green criteria for textile manufacturer supplier selection.

\begin{tabular}{|c|c|c|c|}
\hline Code & Criterion & Code & Criterion \\
\hline $\mathrm{C}_{1}$ & Environmental management system & $\mathrm{C}_{7}$ & Resource/energy consumption \\
\hline $\mathrm{C}_{2}$ & Green packaging & $\mathrm{C}_{8}$ & Green design \\
\hline $\mathrm{C}_{3}$ & Green transportation & $\mathrm{C}_{9}$ & Green technology \\
\hline $\mathrm{C}_{4}$ & Green image & $\mathrm{C}_{10}$ & Green purchasing \\
\hline $\mathrm{C}_{5}$ & Staff environmental management & $\mathrm{C}_{11}$ & Pollution production \\
\hline $\mathrm{C}_{6}$ & Green warehousing & $\mathrm{C}_{12}$ & Waste water \\
\hline
\end{tabular}

Source: own elaboration.

The criteria $\mathrm{C}_{7}, \mathrm{C}_{11}$ and $\mathrm{C}_{12}$ are cost type, the others are benefit type. The spherical fuzzySWARA steps are implemented based on the assessment of each of the seven DM from the company. The importance order of the criteria is given in Table 3. The results are combined by taking the arithmetic mean of the results for seven decision makers and the final criteria weights are calculated as in Table 4. 
Table 3. The orders of importance.

\begin{tabular}{|c|c|c|c|c|c|c|c|}
\hline Order & $\mathbf{D M}_{1}$ & $\mathbf{D M}_{2}$ & $\mathbf{D M}_{3}$ & $\mathbf{D M}_{4}$ & $\mathbf{D M}_{5}$ & $\mathbf{D M}_{6}$ & $\mathbf{D M}_{\mathbf{7}}$ \\
\hline 1 & $\mathrm{C}_{4}$ & $\mathrm{C}_{3}$ & $\mathrm{C}_{1}$ & $\mathrm{C}_{7}$ & $\mathrm{C}_{7}$ & $\mathrm{C}_{10}$ & $\mathrm{C}_{1}$ \\
\hline 2 & $\mathrm{C}_{8}$ & $\mathrm{C}_{6}$ & $\mathrm{C}_{4}$ & $\mathrm{C}_{4}$ & $\mathrm{C}_{3}$ & $\mathrm{C}_{2}$ & $\mathrm{C}_{9}$ \\
\hline 3 & $\mathrm{C}_{1}$ & $\mathrm{C}_{2}$ & $\mathrm{C}_{5}$ & $\mathrm{C}_{3}$ & $\mathrm{C}_{4}$ & $\mathrm{C}_{3}$ & $\mathrm{C}_{4}$ \\
\hline 4 & $\mathrm{C}_{6}$ & $\mathrm{C}_{1}$ & $\mathrm{C}_{7}$ & $\mathrm{C}_{1}$ & $\mathrm{C}_{9}$ & $\mathrm{C}_{4}$ & $\mathrm{C}_{3}$ \\
\hline 5 & $\mathrm{C}_{2}$ & $\mathrm{C}_{4}$ & $\mathrm{C}_{8}$ & $\mathrm{C}_{2}$ & $\mathrm{C}_{2}$ & $\mathrm{C}_{1}$ & $\mathrm{C}_{11}$ \\
\hline 6 & $\mathrm{C}_{9}$ & $\mathrm{C}_{10}$ & $\mathrm{C}_{10}$ & $\mathrm{C}_{8}$ & $\mathrm{C}_{1}$ & $\mathrm{C}_{7}$ & $\mathrm{C}_{8}$ \\
\hline 7 & $\mathrm{C}_{3}$ & $\mathrm{C}_{7}$ & $\mathrm{C}_{11}$ & $\mathrm{C}_{10}$ & $\mathrm{C}_{11}$ & $\mathrm{C}_{9}$ & $\mathrm{C}_{2}$ \\
\hline 8 & $\mathrm{C}_{5}$ & $\mathrm{C}_{11}$ & $\mathrm{C}_{2}$ & $\mathrm{C}_{11}$ & $\mathrm{C}_{5}$ & $\mathrm{C}_{8}$ & $\mathrm{C}_{6}$ \\
\hline 9 & $\mathrm{C}_{10}$ & $\mathrm{C}_{12}$ & $\mathrm{C}_{9}$ & $\mathrm{C}_{12}$ & $\mathrm{C}_{12}$ & $\mathrm{C}_{12}$ & $\mathrm{C}_{7}$ \\
\hline 10 & $\mathrm{C}_{11}$ & $\mathrm{C}_{5}$ & $\mathrm{C}_{3}$ & $\mathrm{C}_{9}$ & $\mathrm{C}_{8}$ & $\mathrm{C}_{6}$ & $\mathrm{C}_{5}$ \\
\hline 11 & $\mathrm{C}_{7}$ & $\mathrm{C}_{8}$ & $\mathrm{C}_{6}$ & $\mathrm{C}_{6}$ & $\mathrm{C}_{10}$ & $\mathrm{C}_{11}$ & $\mathrm{C}_{10}$ \\
\hline 12 & $\mathrm{C}_{12}$ & $\mathrm{C}_{9}$ & $\mathrm{C}_{12}$ & $\mathrm{C}_{5}$ & $\mathrm{C}_{6}$ & $\mathrm{C}_{5}$ & $\mathrm{C}_{12}$ \\
\hline
\end{tabular}

Source: own elaboration.

Table 4. The spherical fuzzy-SWARA results.

\begin{tabular}{|c|c|c|c|c|c|c|c|c|c|}
\hline$C_{n}$ & $\mathrm{DM}_{1}$ & $\mathrm{DM}_{2}$ & $\mathrm{DM}_{3}$ & $\mathrm{DM}_{4}$ & $\mathrm{DM}_{5}$ & $\mathrm{DM}_{6}$ & $\mathrm{DM}_{7}$ & Avg. & Ranking Results \\
\hline $\mathrm{C}_{1}$ & 0,1072 & 0,1029 & 0,1575 & 0,0959 & 0,0853 & 0,0946 & 0,1572 & 0,1144 & 2 \\
\hline $\mathrm{C}_{2}$ & 0,0851 & 0,1132 & 0,0636 & 0,0872 & 0,0896 & 0,1095 & 0,0746 & 0,0890 & 4 \\
\hline $\mathrm{C}_{3}$ & 0,0736 & 0,1627 & 0,0551 & 0,1007 & 0,1087 & 0,1043 & 0,1081 & 0,1019 & 3 \\
\hline $\mathrm{C}_{4}$ & 0,1356 & 0,0936 & 0,1432 & 0,1158 & 0,1035 & 0,0993 & 0,1243 & 0,1165 & 1 \\
\hline $\mathrm{C}_{5}$ & 0,0701 & 0,0452 & 0,1061 & 0,0565 & 0,0739 & 0,0383 & 0,0398 & 0,0614 & 11 \\
\hline $\mathrm{C}_{6}$ & 0,1021 & 0,1302 & 0,0501 & 0,0621 & 0,0580 & 0,0543 & 0,0622 & 0,0741 & 9 \\
\hline $\mathrm{C}_{7}$ & 0,0528 & 0,0740 & 0,0964 & 0,1216 & 0,1141 & 0,0822 & 0,0518 & 0,0847 & 5 \\
\hline $\mathrm{C}_{8}$ & 0,1232 & 0,0430 & 0,0877 & 0,0793 & 0,0640 & 0,0746 & 0,0783 & 0,0786 & 7 \\
\hline $\mathrm{C}_{9}$ & 0,0810 & 0,0391 & 0,0578 & 0,0652 & 0,0941 & 0,0783 & 0,1429 & 0,0798 & 6 \\
\hline $\mathrm{C}_{10}$ & 0,0610 & 0,0851 & 0,0701 & 0,0755 & 0,0609 & 0,1533 & 0,0362 & 0,0774 & 8 \\
\hline$C_{11}$ & 0,0581 & 0,0569 & 0,0668 & 0,0719 & 0,0776 & 0,0517 & 0,0901 & 0,0676 & 10 \\
\hline $\mathrm{C}_{12}$ & 0,0503 & 0,0542 & 0,0455 & 0,0685 & 0,0704 & 0,0597 & 0,0345 & 0,0547 & 12 \\
\hline Tot. & 1,0000 & 1,0000 & 1,0000 & 1,0000 & 1,0000 & 1,0000 & 1,0000 & 1,0000 & \\
\hline
\end{tabular}

Source: own elaboration.

In Step 3, MARCOS method is performed to evaluate the suppliers $\left(\mathrm{A}_{1}, \mathrm{~A}_{2}, \mathrm{~A}_{3}, \mathrm{~A}_{4}, \mathrm{~A}_{5}\right.$, $\mathrm{A}_{6}$ ) by using the criteria weights. The extended initial decision matrix " $X$ " and normalized weighted matrix " $V$ ” are shown in Table 5 and Table 6.

Table 5. The extended initial decision matrix " $X$ ".

\begin{tabular}{|c|c|c|c|c|c|c|c|c|c|c|c|c|}
\cline { 2 - 13 } \multicolumn{1}{c|}{} & $\mathbf{C}_{\mathbf{1}}$ & $\mathbf{C}_{\mathbf{2}}$ & $\mathbf{C}_{\mathbf{3}}$ & $\mathbf{C}_{\mathbf{4}}$ & $\mathbf{C}_{\mathbf{5}}$ & $\mathbf{C}_{\mathbf{6}}$ & $\mathbf{C}_{\mathbf{7}}$ & $\mathbf{C}_{\mathbf{8}}$ & $\mathbf{C}_{\mathbf{9}}$ & $\mathbf{C}_{\mathbf{1 0}}$ & $\mathbf{C}_{\mathbf{1 1}}$ & $\mathbf{C}_{\mathbf{1 2}}$ \\
\hline Weights & 0,1144 & 0,0890 & 0,1019 & 0,1165 & 0,0614 & 0,0741 & 0,0847 & 0,0786 & 0,0798 & 0,0774 & 0,0676 & 0,0547 \\
\hline Type & $\max$ & $\max$ & $\max$ & $\max$ & $\max$ & $\max$ & $\min$ & $\max$ & $\max$ & $\max$ & $\min$ & $\min$ \\
\hline
\end{tabular}




\begin{tabular}{|c|c|c|c|c|c|c|c|c|c|c|c|c|}
\hline AAI & 3,7143 & 3,1429 & 2,1429 & 2,1429 & 4,5714 & 4,0000 & 7,2857 & 4,0000 & 3,8571 & 1,8571 & 8,1429 & 6,8571 \\
\hline$A_{1}$ & 3,8571 & 7 & 0 & 4,2857 & 7,5714 & 3 & 7 & 0 & 1 & 3 & 3 & 0000 \\
\hline$A_{2}$ & 5,0000 & 5,2857 & 5,1429 & 4,0000 & 6,8571 & 4,4286 & 3,0000 & 5,0000 & 5,1429 & 7,0000 & 3,8571 & 6,1429 \\
\hline$A_{3}$ & 5,4286 & 3,2857 & 5,0000 & 6,4286 & 5,0000 & 6,4286 & 7,2857 & 4,8571 & 8,4286 & 8,1429 & 8,1429 & 6,8571 \\
\hline $\mathbf{A}_{4}$ & 3 & 5,8 & 2,1 & 9 & 4,5 & 86 & 43 & 29 & 429 & 571 & 429 & 5,2857 \\
\hline$A_{5}$ & 3,7143 & 3,1429 & 5,0000 & 7,5714 & 7,7143 & 8,1429 & 7,0000 & 4,2857 & 5,0000 & 3,8571 & 3,5714 & 2,7143 \\
\hline$A_{6}$ & 4,4286 & 4,1429 & 3,4286 & 2,1429 & 6,5714 & 4,0000 & 4,5714 & 4,0000 & 4,7143 & 5,0000 & 1,5714 & 4,5714 \\
\hline Al & 6,7143 & 5,8571 & 5,1429 & 7,5714 & 7,7143 & 8,1429 & 3,0000 & 6,1429 & 8,4286 & 8,1429 & 1,5714 & 2,7143 \\
\hline
\end{tabular}

Source: own elaboration.

In the Step 3.4 with the help of the values from Table $4, S_{i}, K_{i}^{+}$and $K_{i}^{-}$values are calculated by Equations (16), (17), and (18). In Step 3.5, $f\left(K_{i}\right)$ values are found for utility functions and scores of alternatives are calculated by Equations (19), (20), and (21). The scores of the alternative suppliers $\left(\mathrm{A}_{1}, \mathrm{~A}_{2}, \mathrm{~A}_{3}, \mathrm{~A}_{4}, \mathrm{~A}_{5}, \mathrm{~A}_{6}\right)$ are shown in Figure 2. According to the results of MARCOS method, the best alternative of green supplier is $\mathrm{A}_{2}$ with the highest score. Second one is $\mathrm{A}_{3}$, and third is $\mathrm{A}_{5}$.

Table 6. Normalized weighted matrix "V".

\begin{tabular}{|c|c|c|c|c|c|c|c|c|c|c|c|c|}
\hline & $C_{1}$ & $\mathrm{C}_{2}$ & $\mathrm{C}_{3}$ & $\mathrm{C}_{4}$ & $C_{5}$ & $\mathrm{C}_{6}$ & $C_{7}$ & $\mathrm{C}_{8}$ & $C_{9}$ & $C_{10}$ & $C_{11}$ & $C_{12}$ \\
\hline Al & 0633 & 0477 & 0425 & 0330 & 0364 & 0364 & 0349 & 0,0512 & 0,0365 & 0,0177 & 0,0130 & 0,0217 \\
\hline$A_{1}$ & & 3 & 0594 & 0050 &, 0000 & 0,0429 & 3 & 0 & 5 & 9 & 8 & 97 \\
\hline$A_{2}$ & 852 & 0,0803 & 0,1019 & 0,0615 & 0,0546 & 0,0403 & 0,0847 & 0,0640 & 0,0487 & 0,0666 & 0,0275 & 0,0242 \\
\hline $\mathrm{A}_{3}$ & 25 & 0,0499 & 0,0991 & 989 & 398 & 0,0585 & 0,0349 & 0,0621 & 0,0798 & 0,0774 & 0,0130 & 0,0217 \\
\hline $\mathbf{A}_{4}$ & 0,1144 & 0 & 425 & 0,0945 & 0,0364 & 44 & 39 & 786 & 0,0392 & 177 & 0,0206 & 0,0281 \\
\hline$A_{5}$ & 0,0633 & 177 & 201 & 0,1165 & 0,0614 & 0,0741 & 63 & 8 & 73 & 0,0367 & 0297 & 0,0547 \\
\hline$A_{6}$ & 0754 & 0,0629 & 0,0679 & 0,0330 & 0,0523 & 0,0364 & 0,0556 & 0,0512 & 0,0446 & 0,0476 & 0,0676 & 0,0325 \\
\hline Al & 0,1144 & 0,0890 & 0,1019 & 0,1165 & 0,0614 & 0,0741 & 0,0847 & 0,0786 & 0,0798 & 0,0774 & 0,0676 & 0,0547 \\
\hline
\end{tabular}

Source: own elaboration.

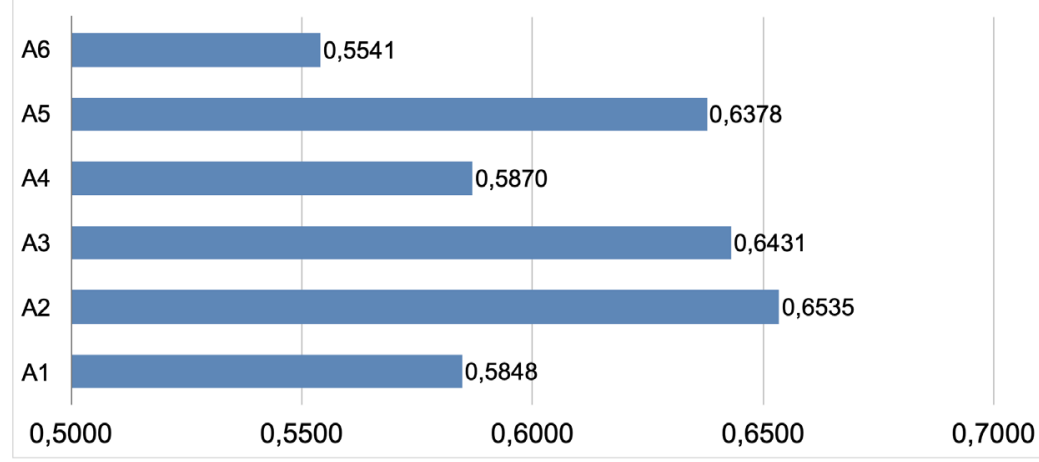

Figure 2. The ranking Scores of Alternatives.

Source: own elaboration. 
To perform a sensitivity analysis of the proposed methodology, thirteen different scenarios are created by changing the weights of the criteria and the results are compared. According to the results, $A_{2}$ is the first and $A_{6}$ is the last in the ranking in all thirteen scenarios. Although ranking results changes in four scenarios, it is generally the same as the results of combined the spherical fuzzy-SWARA-MARCOS method.

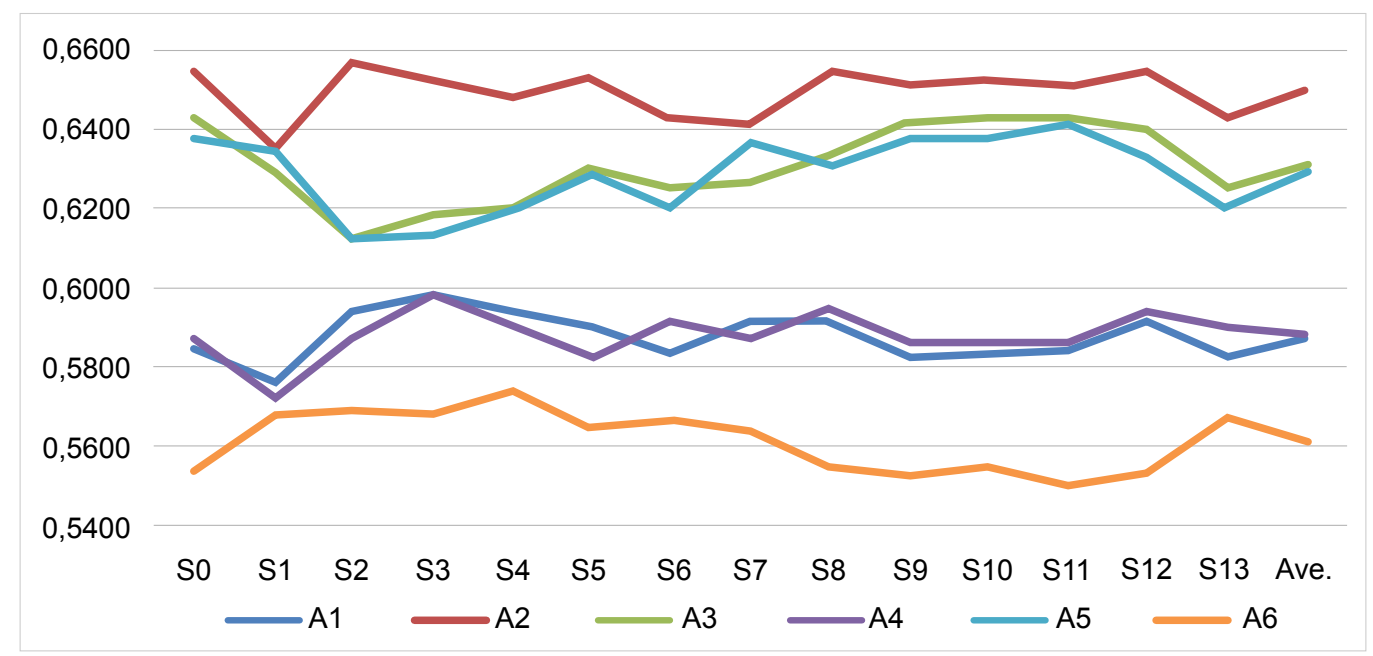

Figure 3. Comparison of different scenarios.

Source: own elaboration.

\section{CONCLUSIONS}

Nowadays, organizations are expected to be environmentally friendly in their supply chains. Therefore, selecting suitable green suppliers in sustainable supply chains is a very important task. In this study, the green supplier selection problem of a textile company is investigated. The spherical fuzzy-SWARA and MARCOS methods are handled in an integrated way. As a result of the combined spherical fuzzy-SWARA method, the highest weight criteria are green image, environmental management system and green transportation, respectively. According to the MARCOS method, the best green supplier is $A_{2}$ and the ranking of alternatives is $A_{2}>A_{3}>A_{5}>A_{4}>A_{1}>A_{6}$. Subsequently, for different scenarios, alternative suppliers are ranked, and the results are compared. Consequently, it is clear that the results of the proposed methodology is consistent. For future studies, the other fuzzy extentions of fuzzy sets can be considered in expressing the views of DMs, and new fuzzy MCDM methods should be implemented for sustainable supply chain problems. 


\section{ACKNOWLEDGEMENTS}

This work has been supported by the Scientific Research Projects Commission of Galatasaray University under grant number \# FBA-2020-1036.

\section{REFERENCES}

Akcan, S., \& Taş, M. A. (2019). Green supplier evaluation with SWARA-TOPSIS integrated method to reduce ecological risk factors. Environmental Monitoring and Assessment, 191(12), 736. https://doi.org/10.1007/s10661-019-7884-3

Akman, G. (2015). Evaluating suppliers to include green supplier development programs via fuzzy c-means and VIKOR methods. Computers \& industrial engineering, 86, 69-82. https://doi.org/10.1016/j.cie.2014.10.013

\section{Alimardani, M., Hashemkhani Zolfani, S., Aghdaie, M. H., \& Tamošaitienè, J.} (2013). A novel hybrid SWARA and VIKOR methodology for supplier selection in an agile environment. Technological and economic development of economy, 19(3), 533-548. https://doi.org/10.3846/20294913.2013.814606

Atanassov, K.T. (1986). Intuitionistic fuzzy sets. Fuzzy Sets and Systems, 20(1), 87-96. https://doi.org/10.1016/S0165-0114(86)80034-3

Badi, I., \& Pamucar, D. (2020). Supplier selection for steelmaking company by using combined Grey-MARCOS methods. Decision Making: Applications in Management and Engineering, 3(2), 37-48. https://doi.org/10.31181/dmame2003037b

Bali, O., Kose, E., \& Gumus, S. (2013). Green supplier selection based on IFS and GRA. Grey Systems: Theory and Application, 3(2), 158-176. https://www.emerald.com/insight/ content/doi/10.1108/GS-04-2013-0007/full/html

Cao, Q., Wu, J., \& Liang, C. (2015). An intuitionsitic fuzzy judgement matrix and TOPSIS integrated multi-criteria decision making method for green supplier selection. Fournal of Intelligent $\mathscr{E}$ Fuzzy Systems, 28(1), 117-126. https://content.iospress.com/articles/ journal-of-intelligent-and-fuzzy-systems/ifs 1281 
Chakraborty, S., Chattopadhyay, R., \& Chakraborty, S. (2020). An integrated D-MARCOS method for supplier selection in an iron and steel industry. Decision Making: Applications in Management and Engineering, 3(2), 49-69. https://doi. org/10.31181/dmame2003049c

Chung, G. G., Ghao, L. G., \& Lou, S. J. (2016). The establishment of a green supplier selection and guidance mechanism with the ANP and IPA. Sustainability, 8(3), 259. https://doi.org/10.3390/su8030259

De Boer, L., Labro, E., \& Morlacchi, P. (2001). A review of methods supporting supplier selection. European journal of purchasing $\mathcal{E}$ supply management, 7(2), 75-89. https:// research.utwente.nl/en/publications/a-review-of-methods-supporting-supplierselection

Dobos, I., \& Vörösmarty, G. (2019). Inventory-related costs in green supplier selection problems with Data Envelopment Analysis (DEA). International Fournal of Production Economics, 209, 374-380. https://doi.org/10.1016/j.ijpe.2018.03.022

Ghenai, G., Albawab, M., \& Bettayeb, M. (2020). Sustainability indicators for renewable energy systems using multi-criteria decision-making model and extended SWARA/ ARAS hybrid method. Renewable Energy, 146, 580-597. https://doi.org/10.1016/j. renene.2019.06.157

Ghorabaee, M. K., Zavadskas, E. K., Amiri, M., \& Esmaeili, A. (2016). Multicriteria evaluation of green suppliers using an extended WASPAS method with interval type-2 fuzzy sets. Fournal of Cleaner Production, 137, 213-229. https://doi. org/10.1016/j.jclepro.2016.07.031

Govindan, K., Kadziński, M., \& Sivakumar, R. (2017). Application of a novel PROMETHEE-based method for construction of a group compromise ranking to prioritization of green suppliers in food supply chain. Omega, 71, 129-145. https:// doi.org/10.1016/j.omega.2016.10.004 
Gündoğdu, F. K., \& Kahraman, G. (2019a). Spherical fuzzy sets and spherical fuzzy TOPSIS method. Fournal of Intelligent \& Fuzzy Systems, 36(1), 337-352. https:// content.iospress.com/articles/journal-of-intelligent-and-fuzzy-systems/ifs181401

Gündoğdu, F. K., \& Kahraman, C. (2019b). Spherical fuzzy analytic hierarchy process (AHP) and its application to industrial robot selection. In International Conference on Intelligent and Fuzzy Systems (pp. 988-996). Springer, Cham.

Hashemkhani Zolfani, S., \& Bahrami, M. (2014). Investment prioritizing in high tech industries based on SWARA-COPRAS approach. Technological and Economic Development of Economy, 20(3), 534-553. https://doi.org/10.3846/20294913.2014.8 81435

He, Y., Lei, F., Wei, G., Wang, R., Wu, J., \& Wei, G. (2019). EDAS method for multiple attribute group decision making with probabilistic uncertain linguistic information and its application to green supplier selection. International Journal of Computational Intelligence Systems, 12(2), 1361-1370. https://www.atlantis-press.com/journals/ ijcis/ 125921808

Hsu, G. W., Kuo, T. G., Chen, S. H., \& Hu, A. H. (2013). Using DEMATEL to develop a carbon management model of supplier selection in green supply chain management. Fournal of cleaner production, 56, 164-172. https://doi.org/10.1016/j. jclepro.2011.09.012

Kaya, S. K., \& Erginel, N. (2020). Futuristic airport: A sustainable airport design by integrating hesitant fuzzy SWARA and hesitant fuzzy sustainable quality function deployment. Fournal of Cleaner Production, 275, 123880. https://doi.org/10.1016/j. jclepro.2020.123880

Ijadi Maghsoodi, A., Ijadi Maghsoodi, A., Mosavi, A., Rabczuk, T., \& Zavadskas, E. K. (2018). Renewable energy technology selection problem using integrated h-swara-multimoora approach. Sustainability, 10(12), 4481. https://www.mdpi. com/2071-1050/10/12/4481/htm 
Ilieva, G., Yankova, T., Hadjieva, V., Doneva, R., \& Totkov, G. (2020). Cloud Service Selection as a Fuzzy Multi-criteria Problem. TEM Journal, 9(2), 484. https://www. temjournal.com/content/92/TEMJournalMay2020_484_495.pdf

Keršuliene, V., Zavadskas, E. K., \& Turskis, Z. (2010). Selection of rational dispute resolution method by applying new step-wise weight assessment ratio analysis (SWARA). Journal of business economics and management, 11(2), 243-258. https://doi. org/10.3846/jbem.2010.12

Keshavarz-Ghorabaee, M., Amiri, M., Zavadskas, E. K., Turskis, Z., \& Antucheviciene, J. (2018). An extended step-wise weight assessment ratio analysis with symmetric interval type-2 fuzzy sets for determining the subjective weights of criteria in multi-criteria decision-making problems. Symmetry, 10(4), 91. https://doi. org/10.3390/sym10040091

Kumar, P., Singh, R. K., \& Vaish, A. (2017). Suppliers' green performance evaluation using fuzzy extended ELECTRE approach. Clean Technologies and Environmental Policy, 19(3), 809-821. https://doi.org/10.1007/s10098-016-1268-y

Liou, J. J., Tamošaitienè, J., Zavadskas, E. K., \& Tzeng, G. H. (2016). New hybrid COPRAS-G MADM Model for improving and selecting suppliers in green supply chain management. International Journal of Production Research, 54(1), 114-134. https:// doi.org/10.1080/00207543.2015.1010747

Mavi, R. K. (2015). Green supplier selection: a fuzzy AHP and fuzzy ARAS approach. International fournal of Services and Operations Management, 22(2), 165-188. https://econpapers.repec.org/article/idsijsoma/ v_3a22_3ay_3a2015_3ai_3a2_3ap_3a165-188.htm

Mijajlović, M., Puška, A., Stević, Ž., Marinković, D., Doljanica, D., Jovanović, S. V., Stojanović, I., \& Beširović, J. (2020). Determining the Competitiveness of Spa-Centers in Order to Achieve Sustainability Using a Fuzzy Multi-Criteria Decision-Making Model. Sustainability, 12(20), 8584. https://doi.org/10.3390/ sul 2208584 
Perçin, S. (2019). An integrated fuzzy SWARA and fuzzy AD approach for outsourcing provider selection. Journal of Manufacturing Technology Management, 30(2), 531-552. https://www.emerald.com/insight/content/doi/10.1108/JMTM-08-2018-0247/ full/html

Puška, A., Stojanović, I., Maksimović, A., \& Osmanović, N. (2020). Project management software evaluation by using the Measurement of Alternatives and Ranking According to Compromise Solution (MARCOS) method. Operational Research in Engineering Sciences: Theory and Applications, 3(1), 89-102. https:/ /www.researchgate. net/profile/Adis-Puska/publication/340491985_Project_meanagment_software_ evaluation_by_using_the_measurement_of_alternatives_and_ranking_according_ to_compromise_solution_MARCOS_method/links/5e8ccd5c92851c2f52885bcd/ Project-meanagment-software-evaluation-by-using-the-measurement-ofalternatives-and-ranking-according-to-compromise-solution-MARCOS-method. pdf

Rani, P., \& Mishra, A. R. (2020). Single-valued neutrosophic SWARA-VIKOR framework for performance assessment of eco-industrial thermal power plants. ICSES Transactions on Neural and Fuzzy Computing, 3(1 1), 1-9.

Smarandache, F. (1998). Neutrosophy: neutrosophic probability, set, and logic: analytic synthesis $\mathbb{E}$ synthetic analysis. American Research Press, Rehoboth.

Sang, X., \& Liu, X. (2016). An interval type-2 fuzzy sets-based TODIM method and its application to green supplier selection. Fournal of the Operational Research Society, 67(5), 722-734. https://doi.org/10.1057/jors.2015.86

Sen, D. K., Datta, S., Patel, S. K., \& Mahapatra, S. S. (2017). Green supplier selection in fuzzy context: a decision-making scenario on application of fuzzy-MULTIMOORA. International Fournal of Services and Operations Management, 28(1), 98-140. https://www. inderscience.com/info/inarticle.php?artid=85907

Stanković, M., Stević, Ž., Das, D. K., Subotić, M., \& Pamučar, D. (2020). A new fuzzy MARCOS method for road traffic risk analysis. Mathematics, 8(3), 457. https:// doi.org/10.3390/math8030457 
Stanujkic, D., Karabasevic, D., \& Zavadskas, E. K. (2015). A framework for the selection of a packaging design based on the SWARA method. Engineering Economics, 26(2), 181-187. https://www.researchgate.net/publication/281832408_A_ Framework_for_the_Selection_of_a_Packaging_Design_Based_on_the_SWARA_ Method

Stevens, G. C. (1989). Integrating the supply chain. International fournal of physical distribution \& Materials Management, 19(8), 3-8. https://www.emerald.com/insight/content/ doi/10.1108/EUM0000000000329/full/html

Stević, Ž., \& Brković, N. (2020). A Novel Integrated FUCOM-MARCOS Model for Evaluation of Human Resources in a Transport Company. Logistics, 4(1), 4. https:// doi.org/10.3390/logistics4010004

Stević, Ž., Pamučar, D., Puška, A., \& Chatterjee, P. (2020). Sustainable supplier selection in healthcare industries using a new MCDM method: Measurement of alternatives and ranking according to COmpromise solution (MARCOS). Computers E Industrial Engineering, 140, 106231. https://doi.org/10.1016/j.cie.2019.106231

Torra, V. (2010). Hesitant fuzzy sets. International fournal of Intelligent Systems, 25(6), 529-539. https://doi.org/10.1002/int.20418

Ulutaş, A., Karabasevic, D., Popovic, G., Stanujkic, D., Nguyen, P. T., \& Karaköy, Ç. (2020). Development of a Novel Integrated CGSD-ITARA-MARCOS DecisionMaking Approach for Stackers Selection in a Logistics System. Mathematics, 8(10), 1672. https://doi.org/10.3390/math8101672

Vesković, S., Stević, Ž., Karabašević, D., Rajilić, S., Milinković, S., \& Stojić, G. (2020). A New Integrated Fuzzy Approach to Selecting the Best Solution for Business Balance of Passenger Rail Operator: Fuzzy PIPRECIA-Fuzzy EDAS Model. Symmetry, 12(5), 743. https://www.researchgate.net/publication/341160799_A_ New_Integrated_Fuzzy_Approach_to_Selecting_the_Best_Solution_for_Business_ Balance_of_Passenger_Rail_Operator_Fuzzy_PIPRECIA-Fuzzy_EDAS_Model 
Yager, R. R. (2013). Pythagorean fuzzy subsets. In 2013 joint IFSA world congress and NAFIPS annual meeting (IFSA/NAFIPS) (pp. 57-61). IEEE. https://www.semanticscholar.org/ paper/Pythagorean-fuzzy-subsets-Yager/7d615595bed34e5499ef0b5f017548eadd $16 \mathrm{dfd} 7$

Yazdani, M., Chatterjee, P., Zavadskas, E. K., \& Zolfani, S. H. (2017). Integrated QFD-MCDM framework for green supplier selection. Fournal of Cleaner Production, 142, 3728-3740. https://doi.org/10.1016/j.jclepro.2016.10.095

Zadeh, L. A. (1965). Fuzzy Sets. Information Control, 8(3), 338-353. https://doi.org/10.1016/ S0019-9958(65)90241-X

Zadeh, L. A. (1975). The concept of a linguistic variable and its application to approximate reasoning-I. Information sciences, 8(3), 199-249. https://doi.org/10.1016/00200255(75)90036-5 